\title{
Intergenerational Learning through Physical Education; A Case Study of the Interaction Between University Students and the Local Elderly
}

\author{
Li- Yuan Cheng ${ }^{1}$, Joyce Say ${ }^{2}$ \\ Department of Sport Science, National Tsinghua University, Hsinchu Taiwan ${ }^{1}$ \\ Graduate School of Tourism and Hospitality Department, Ritsumeikan Asia Pacific University, Oita, Japan ${ }^{2}$
}

\begin{abstract}
In Taiwan, could see a peculiarity where is going to enter an aging society. From that point forward, the service of instruction needs to underwrite senior learning training. Which urges schools and colleges to satisfy their social obligations, and anticipates that instructors and understudies should execute nearby administrations and activity rehearses. The inspiration of planning cross-generational communication exercises with older individuals through actual games activities. Is to improve the expert information and abilities preparing of sports and wellbeing advancement direction expected by the maturing society and the work environment, and to upgrade the extensive direction capacity of the great quality games and wellbeing advancement industry.
\end{abstract}

Keywords: Intergenerational Learning, Physical Education, Elderly People, Health Promotion, Taiwan

\section{INTRODUCTION}

The issue of having an elderly aging population has become a serious trend in Taiwan. To assist with tackling the issue, this paper will underline the connections of how physical sports education allow elderly people to be active in a healthy way. Despite the known contribution of sport to health and well-being, sport participation declines in older age; however for some people, sport continues to play an important role in older age and may contribute to improved health and wellbeing in older years (Stenner, Buckley, \& Mosewich, 2019). Back in 2006, the Ministry of Education had released an education policy for the elderly, mainly to advocate the importance of having "Intergenerational Learning" together with the younger ones. The concept of the intergenerational learning is allowing elderly to enhance self- efficacy, interact with the younger generation, and lastly to find fill out their own emptiness. In order to achieve the goal, this paper will conduct a cross- generational interaction activities. Where students are mainly from a physical education university department background, and will be planning interactive physical sports activities for elders to exercises.

\section{THE IMPORTANCE OF INTERGENERATIONAL LEARNING}

As time goes by, in Taiwan, could see a phenomenon where is about to enter a super- aged society. Since then, the Ministry of education has endorse senior learning education. Which encourages colleges and universities to fulfill their social responsibilities, and expects teachers and students to implement local services and action practices. According to The Ministry of Education (2019), promotes the University Social Responsibility (USR) plan, with "local connection" and "talent cultivation" as the core. To achieve the true meaning of university social responsibility implementation . In the process of intergenerational learning, they learned the moral connotations of "respect", "hard work and cooperation", "help and leadership", and then "transferred" what they learned to other areas of life, which is in line with the Ministry of Education's promotion of the 12-year state education. The core spirit of the literacy-oriented curriculum extends "literacy" to higher education and even social education. In fact, in 2018, Taiwan has been promoting University Social Responsibility Projects, allowing universities to emerge as active contributors to local sustainability (Executive Yuan, 2019). As a guidance through humanistic care to solve the problem, along with fulfilling the social responsibility. In the manner of (Executive Yuan, 2019) list out the five development strategies (Figure 1) as a guidance of how and why it is relevant, as follows: 


\section{International Advanced Research Journal in Science, Engineering and Technology}

Impact Factor $7.105 \div$ Vol. 9, Issue 2, February 2022

DOI: 10.17148/IARJSET.2022.9203

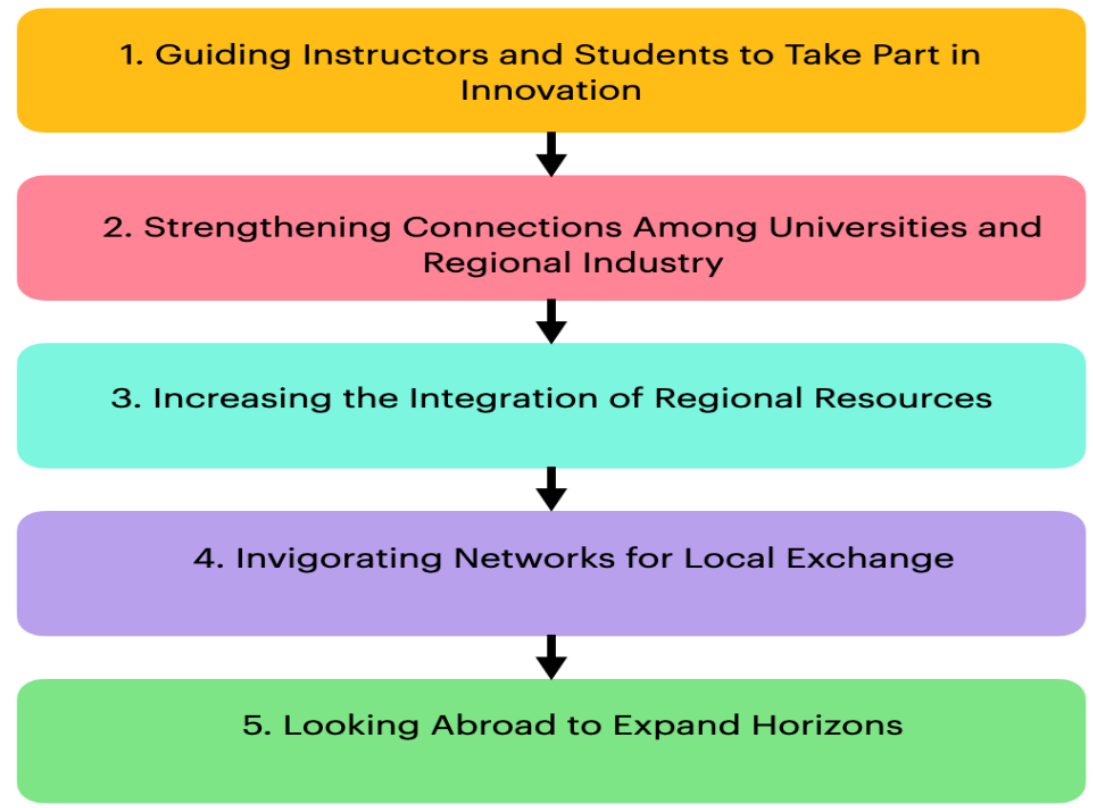

Figure 1: Five Development Strategies (Executive Yuan, 2019).

1. Guiding Instructors and Students to Take Part in Innovation

- Universities are encouraged to develop new coursework and activities

- $\quad$ Students are steered toward self-directed study

- $\quad$ On- site hands-on learning and cooperative approach to study

\section{Strengthening Connections Among Universities and Regional Industry}

- Universities are urged to develop innovative, integrated and multidisciplinary technology that is centered on users and guided by local needs

- $\quad$ Aim social value of cooperation between academia and industry

3. Increasing the integration of Regional Resources

- $\quad$ Develop a partnership of mutual assistance

- $\quad$ Accelerate system transformation and the integration of regional resources

4. Invigorating Networks for Local Exchange

- Universities are encouraging faculty and students to engage in public discourse with local interests

- $\quad$ Develop the region's unique strengths, and design mechanisms to align supply and demand

\section{Looking Abroad to Expand Horizons}

- $\quad$ Firmly rooted local foundations

- $\quad$ Schools can march steadily toward greater participation in the international community

From these factors, from a universities students perspective, developing an intergenerational learning program can help them to be more convinced that their future is not just a physical education teacher. But more likely to be a professions who have contribute to the society and become a lifelong career in the future. In order to overcome the physical and metal barriers, universities students (younger generation) have design physical sports activities education for elderly people to enjoy together and get along with the younger ones.

Moreover, the motivation of designing cross- generational interaction activities with elderly people through physical sports activities. In (Figure 2) shows why intergenerational learning is relevant, and how it benefit each other's by cooperating together. Not only it can increase their self- learning efficiency or cultivate their attitudes of caring and respect. But it's more about maintaining their health. However, the main learning goal is to enhance the professional 


\section{International Advanced Research Journal in Science, Engineering and Technology \\ Impact Factor 7.105 $\div$ Vol. 9, Issue 2, February 2022 \\ DOI: 10.17148/IARJSET.2022.9203}

knowledge and skills training of sports and health promotion guidance required by the aging society and the workplace, and to enhance the comprehensive guidance ability of the high-quality sports and health promotion industry.

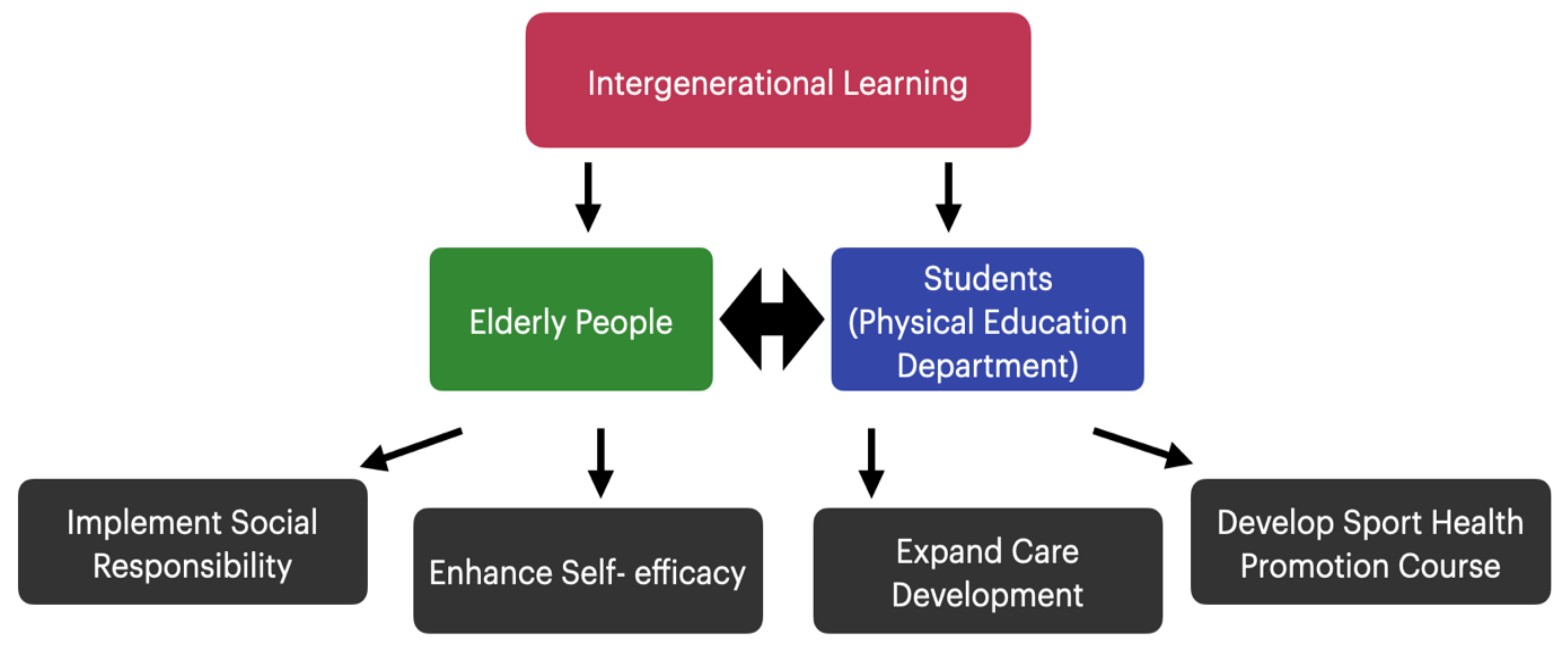

Figure 2: Overview Framework of Intergenerational Learning

\section{Physical Edution Benefit in Health}

Although the health-related benefits of participating in sport are commonly reported, the reasons why some older adults continue to play sport are not well understood (Stenner, Buckley, \& Mosewich, 2019). Until, there is a strong evidence saying that physical activity improves physical function and reduces the risk of age-related loss of physical function in a dose-response manner among the general aging population and improves physical function in older people with frailty and with Parkinson's disease (DiPietro, 2019). Especially, targeting elderly who is over 55 years old, can maintain their healthiness if they continue to play sports. In terms of assimilation issues, the professionalism and diversification of education and learning content, do still have room for improvement. The goal is to hoped that it's stable enough to be established and continuously promote to become a social practice. That it could be lifelong learning ability, for elders to experience in their lifetime. For example, activities that relate to sports departments, health care, recreational manual therapy, aromatic essential oils, tourism, the habit of humanistic care, or even diet. In fact, older adult play sport for a range of health- related and social reasons that can contribute to the experience of successful ageing; based population health is expected to decline over the coming decades as our population ages, being as physically active as possible into older age will become increasingly important for maintaining population health and well-being (Stenner, Buckley, \& Mosewich 2019).

\section{MeTHODOLOGY}

This paper will be using qualitative data, by conducting a short- interview, targeting universities students (from physical education department) to answer. Mainly wanting to find out their opinions about teaching and educating the elders. Due to the social changes in the society, aging declining have become a coming issues. To reduce the issues, the demand for sports, leisure and health industry can be interpret as an option for senior and youth to bond together once again. With the help by inputting teachers and students of the physical education department of colleges and universities to serve the elderly locally, and promote the integration of the intergenerational learning plan. must have in addition to the training of sports professional skills.

The purpose of developing the scale items is to understand the willingness of college students to undertake personal and social responsibilities before and after participating in the course. Where the term self- efficacy often refers to "an individual's perception or belief that he or she can take adaptive behavior in the face of challenges in the environment", a person who believes that he can handle various things well (Schwarzer, 1993). Specially, the course module of sports and health promotion are used for a guidance for elders to determine the significant of moving. In 


\section{International Advanced Research Journal in Science, Engineering and Technology \\ Impact Factor 7.105 ㄷ Vol. 9, Issue 2, February 2022 \\ DOI: 10.17148/IARJSET.2022.9203}

2018 PAGAC Scientific Report provides strong provides strong evidence that physical activity reduces the risk of fallrelated injuries in older people by $32-40 \%$, and this includes severe falls requiring medical care or hospitalization (DiPietro, 2019).

\section{FINDING AND ANALYSIS}

Intergenerational learning brings together people of all ages in mutually beneficial learning experiences; it also provides an opportunity for young students have an authentic audience (Mishkin, 2019). Through physical education activities, the universities students can used their profession to play along with the elderly people, for them to be active in a healthy way. As for the result (Table 1), there are eight participants who are students that are from physical education background.

Table 1: Eight Interviewee during the Intergenerational Learning Activity.

\begin{tabular}{|c|l|}
\hline Participants & Opinions about Teaching and Educating Elders \\
\hline A & $\begin{array}{l}\text { Exercise guidance course is very useful, and it also allows us to communicate with the } \\
\text { elders }\end{array}$ \\
\hline B & $\begin{array}{l}\text { Learn how to get close with elders, with this project learning, I have improve the } \\
\text { communication skills with the elders }\end{array}$ \\
\hline C & $\begin{array}{l}\text { Throughout the physical education activity, I found that the most important is the } \\
\text { social responsibility and the process of interacting with them } \\
\text { As an accompany to listen to their needs }\end{array}$ \\
\hline D & $\begin{array}{l}\text { Although there are an age gap between, but because of the intergeneration learning, we } \\
\text { become closer } \\
\text { They have also ask me about sports knowledge, how it can act for health promotion, } \\
\text { the elders are willing to involve }\end{array}$ \\
\hline E & $\begin{array}{l}\text { This physical education interaction class allows us to understand not only the physical } \\
\text { and mental knowledge of the elderly in the aging society }\end{array}$ \\
\hline F & $\begin{array}{l}\text { After the class, I have a better understanding of knowing how to plan events for the } \\
\text { elderly people }\end{array}$ \\
\hline G & $\begin{array}{l}\text { This allows me to practice at home with my grandparents and serve as a bridge to } \\
\text { connect emotionally }\end{array}$ \\
\hline H & $\begin{array}{l}\text { This cross generational course allows we younger generation to bring happiness for the } \\
\text { elders, together exercising aiming for healthy body }\end{array}$ \\
\hline
\end{tabular}

Due to the serious covid19 pandemic in Taiwan, there are only eight participants (interviewee). As a matter of fact, within the eight participants, the results prove that having an intergenerational learning can be an objective to improve the complete direction capacity of the great quality games and wellbeing advancement industry. Not just it can expand their self-learning effectiveness or develop their mentalities of mindful and regard. Yet, it's more about keeping up with their wellbeing. Notwithstanding, the fundamental learning objective is to upgrade the expert information and abilities preparing of sports and wellbeing advancement direction expected by the maturing society and the work environment. More likely, with the assist of universities, it accomplish the following points. Care for the surrounding locale, industrial collaboration, a sustainable environment, food safety and long-term care, and other social obligations; especially the proposed projects should produce tangible result in building local connections and delivering the benefits of enhanced regional development (Executive Yuan, 2019).

\section{CONCLUSION}

To conclude, from the subjective information of this venture, clearly the "Intergenerational Learning" model can to be sure improve the social obligation, profession advancement potential, and learning self-viability of understudies in the actual instruction division of schools and colleges. From the participants results it tends to be observed commonly that they comprehend the requirements and hardships of the elders by cooperating with the seniors. Simultaneously, selfassurance can be found from the input, genuine mentality, looks, and expressions of the elderly people, which is of conclusive assistance to vocation improvement and conviction. Furthermore, to defeat the mental obstructions of coexisting with new seniors and instigate the seniors to become inspired by the courses they planned, the understudies of the Division of Physical Education can attempt through collaboration, to tackle the mechanical distance of the seniors. 


\section{International Advanced Research Journal in Science, Engineering and Technology}

Impact Factor $7.105 \div$ Vol. 9, Issue 2, February 2022

DOI: 10.17148/IARJSET.2022.9203

\section{REFERENCES}

1. [2]. Stenner J. B., Buckley, D. J., \& Mosewich, D. A., (2019). Reasons why older adults play sport: A systematic review. Elsevier.

2. DiPietro, L. (2019). American College of Sports Medicine Leading the Way. Physical Activity and Function in Older Age: It's Never too Late to Start. https://www.acsm.org/blog-detail/acsm-blog/2019/09/10/physical-activityfunction-older-age

3. Mishkin, K. (2019). Digital Promise, Accelerating Innovation in Education. How to Create Powerful Intergenerational Learning Experiences. https://digitalpromise.org/2019/06/27/how-to-create-powerfulintergenerational-learning-experiences/

4. Executive Yuan (2019). University Social Responsibility. Department of Information Services. https://english.ey.gov.tw/News3/9E5540D592A5FECD/0bf4aaf5-7332-44d7-bc6c-55d9a4e2a590

5. $\quad$ Schwarzer, R., \& Jerusalem, M. (1995). Generalized Self-Efficacy scale. In J.

Weinman, S. Wright, \& M. Johnston, Measures in health psychology: A user's portfolio. Causal and control beliefs (pp. 35-37). Windsor, UK: NFER-NELSON.

6. The Ministry of Education (2019) 「在地實踐 放眼國際」(Local Practice and International Vision)-第二期 大學社會責任實踐計畫審查 (Phase 2 Review of University in Social Responsibility Program.

7. https://www.edu.tw/News_Content.aspx?n=9E7AC85F1954DDA8\&sms=169B8E91BB75571F\&s=E14C9B3 5E0AD3A14 